Review

\title{
Ferritin: A Platform for MRI Contrast Agents Delivery
}

\author{
Maria Rosaria Ruggiero, Diego Alberti, Valeria Bitonto and Simonetta Geninatti Crich * (D) \\ Department of Molecular Biotechnology and Health Sciences, University of Torino, via Nizza 52, \\ 10126 Torino, Italy; mariarosaria.ruggiero@unito.it (M.R.R.); diego.alberti@unito.it (D.A.); \\ valeria.bitonto@unito.it (V.B.) \\ * Correspondence: simonetta.geninatti@unito.it; Tel.: +39-011-6706473
}

Received: 13 January 2019; Accepted: 25 February 2019; Published: 2 March 2019

\begin{abstract}
The search for high relaxivities and increased specificity continues to be central to the development of paramagnetic contrast agents for magnetic resonance imaging (MRI). Ferritin, due to its unique surface properties, architecture, and biocompatibility, has emerged as a natural nanocage that can potentially help to reach both these goals. This review aims to highlight recent advances in the use of ferritin as a nanoplatform for the delivery of metal-based MRI contrast agents (containing $\mathrm{Gd}^{3+}, \mathrm{Mn}^{2+}$, or $\mathrm{Fe}_{2} \mathrm{O}_{3}$ ) alone or in combination with active molecules used for therapeutic purposes. The collected results unequivocally show that the use of ferritin for contrast agent delivery leads to more accurate imaging of cancer cells and a significantly improved targeted therapy.
\end{abstract}

Keywords: ferritin; relaxation; molecular imaging; gene expression reporters; theranostic agents

\section{Introduction}

Specific delivery by naturally occurring macromolecules has been explored for a long time to improve the diagnostic potential of magnetic resonance imaging (MRI) contrast agents (CAs). The MRI signal is dependent on the longitudinal $\left(\mathrm{T}_{1}\right)$ and transverse $\left(\mathrm{T}_{2}\right)$ proton relaxation times of water and, therefore, the image contrast arises mainly from differences in the $T_{1}$ and $T_{2}$ of tissue water protons as a consequence of the water interaction with biological macromolecules and membranes. In both clinical and experimental settings, the endogenous contrast can be altered by the use of CAs that decrease the $T_{1}$ and $T_{2}$ of water protons in the tissues where they distribute [1-3], with the $T_{1}$ and $T_{2}$ values having opposite effects on the $T_{1}$ - and $T_{2}$-weighted images. A $T_{1}$ decrease causes a signal intensity (SI) increase (positive contrast), whereas a $\mathrm{T}_{2}$ decrease causes an SI decrease (negative contrast). The interaction of CAs with macromolecules (i.e., proteins) has the double advantage of increasing both the targeted delivery and the contrast efficiency that is related to the tumbling rate reduction. As CAs are intravenously administered, the first protein considered was serum albumin [4]. Binding with serum albumin modulates CA extravasation, thus allowing dynamic contrast enhanced (DCE) protocols devoted to the detection of parameters related to vascular permeability and blood flow to occur [5]. Lipoproteins have also been proposed in many preclinical studies for the delivery of lipophilic CAs with the aim of targeting atherosclerotic plaques [6] or tumor tissues [7]. Due to their low concentration in blood, a concentrated lipoprotein solution is administered to the animal model after CA loading. Ferritin, a ubiquitously expressed protein that is the main iron cellular storage molecule in the body [8], has also been extensively studied for the delivery of biologically active molecules or metal ions in many biomedical applications. However, in addition to iron, ferritin has the unique ability to encapsulate and deliver other molecules. Many recent reviews have focused on various aspects of the use of this nanocage as a drug delivery system $[9,10]$. This review aims to discuss the peculiar role of an apoferritin cage not only for the specific delivery of MRI CAs but 
also to obtain significant relaxivity enhancement with consequent efficacy improvement. Ferritin is a nanocage composed of 24 subunits of heavy $(\mathrm{H})$ - and/or light (L)-chain peptides, with either ferroxidase activity or iron nucleation ability, respectively. These peptide chains are present in different ratios in various organs to form a cage architecture of $12 \mathrm{~nm}$ in external diameter with an interior cavity of $8 \mathrm{~nm}$ [11]. Although functions of ferritin are traditionally associated with intracellular iron storage, recent studies have demonstrated ferritin ability for iron delivery and transport [9]. In particular, studies have demonstrated $\mathrm{H}$-ferritin-mediated iron delivery to the brain through the blood-brain barrier, demonstrating that $\mathrm{H}$-ferritin can replace transferrin as an iron source for oligodendrocytes in vitro [12]. Other studies have demonstrated both $\mathrm{H}$ - and L-ferritin binding and endocytosis in a number of different cell types, including hepatocytes [13], reticulocytes [14], lymphoid cells [15], erythroid precursors [16], and cancer. The receptors involved belong to human scavenger receptor class A member 5 (SCARA5) [17] for L-ferritin and to murine TIM-2 [18] and human transferrin receptor 1 (TfR-1) [19] for H-ferritin, respectively. Thus, without any modification of the protein cage, it can be exploited for the delivery of CAs in pathologies overexpressing these receptors [20] (Figure 1). Furthermore, perturbations in cellular ferritin are emerging as an important element in the pathogenesis of neurodegenerative and vascular diseases, inflammatory states, and breast, colon and liver cancers [21]. These perturbations can be related to an up or downregulation of ferritin cell receptors. In fact, it is well known that fast proliferating tumor cells abnormally express TfR-1 due to their increased iron consumption [22]. Moreover, there is a highly variable expression of SCARA 5 by different mammary or hepatoma cancer cells that plays a critical role in pathology progression and metastasis by inactivating different signaling pathways $[23,24]$. However, the expression of TfR- 1 and SCARA5 on both normal hepatocytes and other tissues can increase ferritin clearance through the bloodstream, thus reducing its accumulation at the target site. To increase targeted ferritin delivery, more selective ligands of cell surface markers, such as peptides and antibodies, have been conjugated to the external surface of ferritin [25]. In this contest, Khoshnejad M. et al. have shown high pulmonary endothelial targeting in vivo, with no noticeable undesired effects, by functionalizing ferritin with antibodies specific for ICAM-1 [26]. The present review aims to highlight recent advances achieved using both $\mathrm{H}$ - and L-ferritins, loaded with paramagnetic metals or complexes, as highly sensitive MRI probes (Figure 1). Loading into the protein cavity enables the imaging probes to report on ferritin receptor expression that is involved in the progression of many diseases.

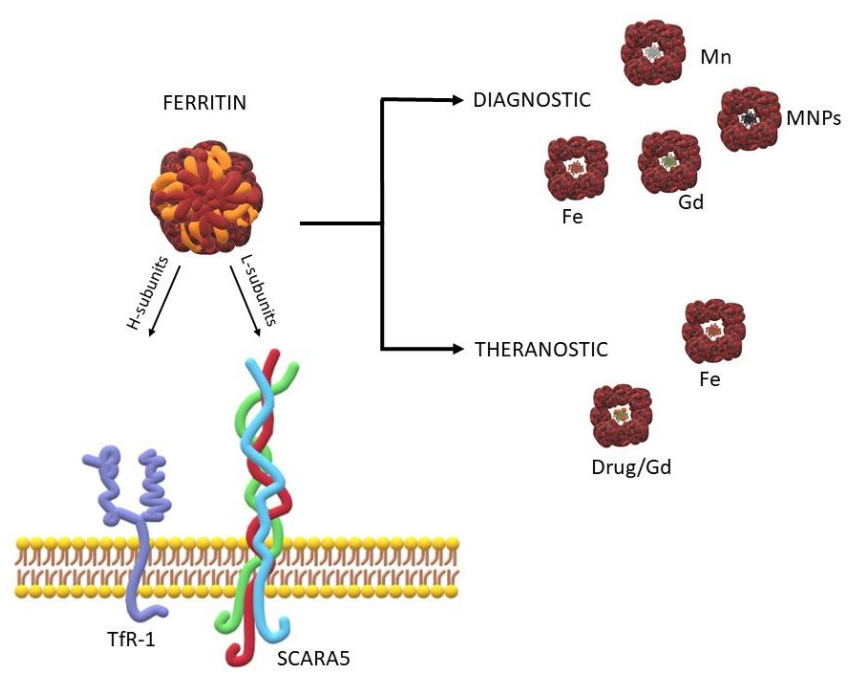

Figure 1. Schematic representation of the use of ferritin for diagnostic and theranostic purposes. The protein cage can be loaded with magnetic resonance imaging (MRI) contrast agents containing paramagnetic ions ( $\mathrm{Gd}, \mathrm{Fe}, \mathrm{Mn}$ ), magnetic nanoparticles (MNPs) and drugs. Human transferrin receptor 1 (TfR-1) and human scavenger receptor class A member 5 (SCARA5) are the natural ferritin cell-surface receptors for $\mathrm{H}$ - and L-ferritin subunits, respectively. 


\section{Gd-Loaded Apoferritin}

One of the basic issues of fundamental importance in the development of Gd(III)-based MRI contrast agents is the search for very high relaxivities [27]. The intrinsic proton relaxivity of Gd ions is decreased by the formation of chelates such as Gd-1,4,7,10-Tetraazacyclododecane-1,4,7,10-tetraacetic acid (Gd-DOTA) and Gd-diethylenetriaminepentacetatic acid (Gd-DTPA) (Figure 2A,B), leading to their administration in large doses in the clinic and, therefore, enhancing the risk of toxic effects. A possible strategy to enhance the efficiency and increase the specific accumulation of CAs is based on their inclusion into the apoferritin cavity. This central core (of ca. $8 \mathrm{~nm}$ ) can hold many CA units. At the intersection of the subunits, channels of 3-4 $\AA$ in diameter allow the diffusion of water into the cavity but not of larger molecules i.e., with the size of commonly used CAs (8-9 ^) [28].
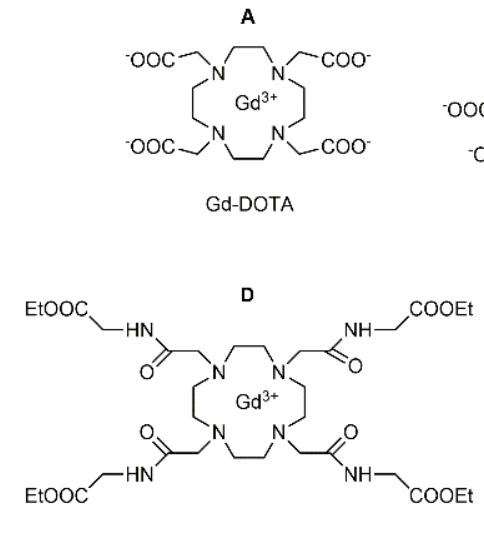

Gd-DOTA-tetra(amide)

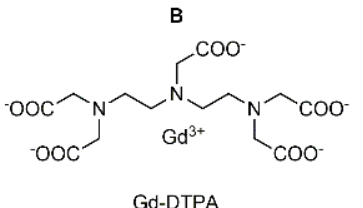

Gd-DTPA

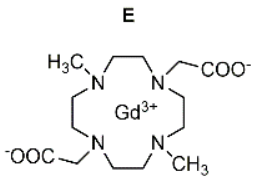

$\mathrm{Gd}-\mathrm{Me}_{2} \mathrm{DO} 2 \mathrm{~A}$
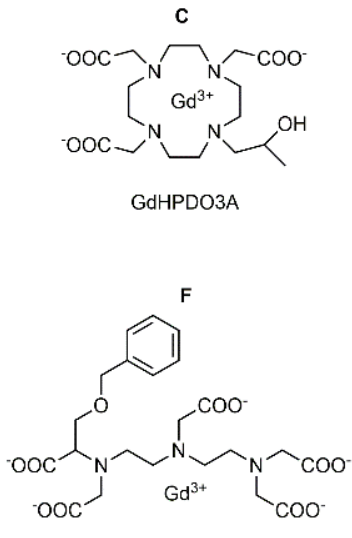

Gd-BOPTA

Figure 2. Chemical structures of Gd-based MRI contrast agents (CAs): (A) Gd-DOTA, (B) Gd-DTPA, (C) Gd-HPDO3A, (D) Gd-DOTA-tetra(amide), (E) Gd-Me 2 DO2A and (F) Gd-BOPTA.

Different strategies for trapping small molecules in the apoferritin core were reported [29]. The procedure first indicated by Aime and coworkers [30] consisted of the dissociation of horse spleen apoferritin (HoS-apoferritin) into subunits at $\mathrm{pH} 2$ followed by its reassociation at $\mathrm{pH}$ 7.4. In this way, the CA molecules that dissolved in the solution were trapped within its interior (Figure 3).

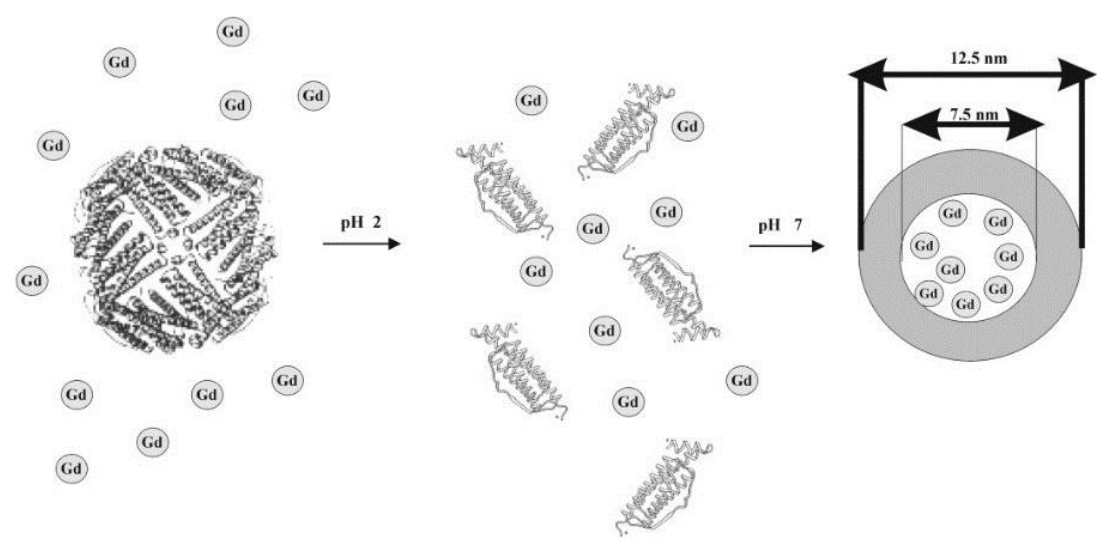

Figure 3. Schematic representation of the dissociation of apoferritin into subunits at $\mathrm{pH} 2$, followed by its reforming at $\mathrm{pH}$ 7. In this way, the solution components were trapped within its interior. Reproduced with permission from [30]. Copyright John Wiley and Sons, 2002.

Using this method, Aime and coworkers obtained the entrapment of ca. $10 \mathrm{Gd}-2,2^{\prime}, 2^{\prime \prime}-[10-(2-$ hydroxypropyl)-1,4,7,10-tetraazacyclododecane-1,4,7-triyl]triacetic acid (Gd-HPDO3A) units per apoferritin molecule (Gd-Apo). Gd-HPDO3A (Figure 2C) is a commercially available (trade name 
ProHance ${ }^{\circledR}$ ) neutral complex that displays one coordinated water molecule in fast exchange with bulk water. When encapsulated in the interior core of apoferritin, Gd-HPDO3A has a longitudinal relaxivity $\left(\mathrm{r}_{1}\right)$ of $80 \pm 5 \mathrm{mM}^{-1} \mathrm{~s}^{-1}$ per $\mathrm{Gd}^{3+}$ atom at $0.5 \mathrm{~T}$ and $25^{\circ} \mathrm{C}$, a value that is almost 20 times higher with respect to the free complex in water $\left(4.2 \mathrm{mM}^{-1} \mathrm{~s}^{-1}\right)$. The success of this cavity to attain high relaxivities results from the exploitation of a large protein surface strongly interacting with the paramagnetic complexes. Such unusual high relaxivity cannot be explained by standard paramagnetic relaxation theory for $\mathrm{Gd}(\mathrm{III})$ chelates containing a single inner-sphere water molecule. To explain this relaxivity, Aime and coworkers highlighted the importance of additional contributions assigned to water molecules and exchangeable protons on the protein surface in the proximity of the Gd(III) complex binding site(s). The loading of 8-10 Gd-HPDO3A units inside the protein cavity generates various interactions between the paramagnetic centers, the water molecules (free moving within the cavity or $\mathrm{H}$-bonded to the inner protein surface), and exchangeable protons, in turn producing an overall highly relaxing sink. The fundamental role of these second sphere protons in the determination of such a large relaxivity increase was confirmed by Vasalatiy et al. [31] a few years later. In fact, they repeated the same entrapment experiment using a Gd-DOTA-tetra(amide) (1,4,7,10-tetraazacyclododecane tetrakis (ethyl-acetamidoacetate)) (Figure 2D) without inner sphere-coordinated water molecules ( $q=0$ ) obtaining an $r_{1}$ of the encapsulated complex of $60 \pm 4 \mathrm{mM}^{-1} \mathrm{~s}^{-1}$ (whereas the free complex $\mathrm{r}_{1}$ was $2.1 \mathrm{mM}^{-1} \mathrm{~s}^{-1}, 0.5 \mathrm{~T}, 25^{\circ} \mathrm{C}$ ). The authors concluded that the substantial increase in relaxivity must be attributed to: (i) a rapid prototropic exchange between the internal protein surface and freely moving water confined in the inner-core and (ii) further enhancements related to the rotational slowing of the complex due to the interaction with the inner-core surface residues. In 2010, Fries and Belorizky [32] presented a theoretical model applied to the apoferritin system to calculate the relaxivity of $\mathrm{Gd}(\mathrm{III})$ complexes encapsulated inside water-permeable nanovesicles. In agreement with Aime et al. [30], the 1/ $T_{1}$ nuclear magnetic resonance dispersion (NMRD) theoretically predicted profile of Gd-HPDO3A trapped inside apoferritin vesicles matched perfectly with the one acquired experimentally. The model showed that the second/outer-sphere relaxivity dominates with respect to the inner-sphere contribution. To improve the entrapment efficiency, Makino and coworkers [33] took advantage of the intrinsic property of apoferritin to condense cations in its cavity. A positively charged Gd-4,10-dimethyl-1,4,7,10-Tetraazacyclododecane-1,7-diacetic acid (Gd-Me ${ }_{2} \mathrm{DO} 2 \mathrm{~A}$ ) (Figure 2E) was used for this purpose. Using the $\mathrm{pH}$-dependent encapsulation procedure, about $11 \mathrm{Gd}-\mathrm{Me}_{2} \mathrm{DO} 2 \mathrm{~A}$ units were trapped inside the protein cavity but the apoferritin recovery rate was low (25\%). Thus, the authors modified the reassembling protocol by slowly increasing the $\mathrm{pH}$ from 2 to 4 before the addition of the positive Gd-chelate. At $\mathrm{pH} 7$, the apoferritin recovery rates increased over $90 \%$. The highest Gd-Me ${ }_{2} \mathrm{DO} 2 \mathrm{~A} \mathrm{r}_{1}\left(35.9 \mathrm{mM}^{-1} \mathrm{~s}^{-1}\right.$ at $\left.1.5 \mathrm{~T}\right)$ was obtained when a maximum of 11 units were loaded in the protein cavity. Increasing this number from 11 to ca. 36 caused an $r_{1}$ decrease to $19.6 \mathrm{mM}^{-1} \mathrm{~s}^{-1}$. The authors surmised this decrease with a limited number of strong $\mathrm{Gd}-\mathrm{Me}_{2} \mathrm{DO} 2 \mathrm{~A}$ binding sites on the apoferritin inner surface. After the encapsulation of $\mathrm{Gd}-\mathrm{Me}_{2} \mathrm{DO} 2 \mathrm{~A}$, the apoferritin outer surface was modified with dextran to enhance the in vivo blood clearance time. The protein diameter increased up to $30 \mathrm{~nm}$. A completely different approach was reported by Sanchez et al. [34] In this study, Gd(III) metal oxide or oxyhydroxides were formed directly inside the apoferritin cavity after the addition of $\mathrm{Gd}\left(\mathrm{NO}_{3}\right)_{3}$ at $\mathrm{pH} 8$ to the protein solution. The $\mathrm{Gd}(\mathrm{III})$ not trapped inside the cavity but weakly bound to the external protein surface was eliminated by adding ethylenediaminetetraacetic acid (EDTA) to the Gd(III)-apoferritin solution. Finally, a total of $1700 \mathrm{Gd}(\mathrm{III})$ per protein was obtained.

Besides the establishment of a well-designed model with high relaxivities, Gd-loaded apoferritin was used to obtain an in vitro and in vivo contrast enhancement in MR images of tumors. Makino et al. [33] performed MRI studies of adenocarcinoma-bearing mice and showed that the $\mathrm{GdMe}_{2} \mathrm{DO} 2 \mathrm{~A}$ apoferritin system successfully accumulated in the tumor region as a consequence of the enhanced permeation and retention effect. A well detectable signal intensity (SI) enhancement of the tumor region was measured using a Gd dose of $0.02 \mathrm{mmol} / \mathrm{kg}$, i.e., five times lower than that used with standards CAs. Geninatti Crich and coworkers [35] developed a targeting method to visualize 
angiogenesis by MRI through the specific recognition of the neural cell adhesion molecule (N-CAM), which is stably expressed by neoformed tumor endothelial cells (TECs). In this study, streptavidin was used as a linker between a biotinylated-apoferritin, loaded with Gd-HPDO3A, as described above [28], and a biotinylated targeting peptide (C3d-Bio) able to bind N-CAM molecules on TECs. Gd-HPDO3A remained entrapped in the protein cavity also after its binding to the N-CAM receptor, as demonstrated by its NMRD profile that showed the same bell-shaped behavior with an $r_{1}$ hump at $0.8 \mathrm{~T}(35 \mathrm{MHz})$ observed in buffer solution (Figure 4).

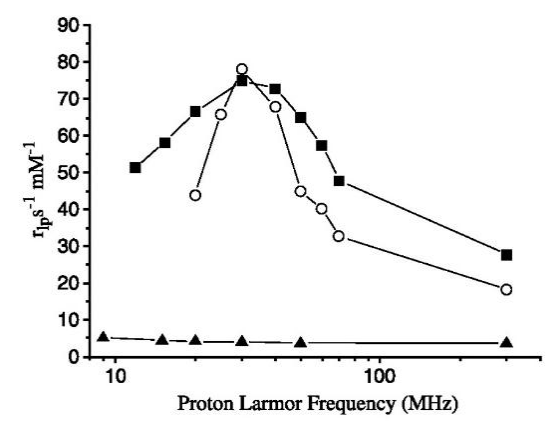

Figure 4. $1 / \mathrm{T}_{1}{ }^{1} \mathrm{H}$-nuclear magnetic resonance dispersion (NMRD) profile (9-300 $\mathrm{MHz}(\mathrm{pH} 7)$ and $25{ }^{\circ} \mathrm{C}$ ) of free Gd-HPDO3A $(\boldsymbol{\Lambda})$ compared with Gd-Apo before $(\boldsymbol{\square})$ and after binding to tumor endothelial cells (TECs) (O). Reproduced with permission from [35]. Copyright American Association for Cancer Research, 2006.

In vivo, a marked SI enhancement $(>30 \%)$ was observed in the tumor region $5 \mathrm{~h}$ after the $\mathrm{C} 3 \mathrm{~d}$-targeted Gd-loaded apoferritin administration with respect to the non-targeted one (3-5\%), in a mouse model of tumor angiogenesis obtained by injecting TEC cells subcutaneously, in matrigel, in Severe Combined ImmunoDeficient (SCID) mice (Figure 5). The Gd dose administered $(0.01 \mathrm{mmol} / \mathrm{kg})$ was 10 times lower than the dose currently used for Gd-based CAs in clinical protocols $(0.1 \mathrm{mmol} / \mathrm{kg})$.

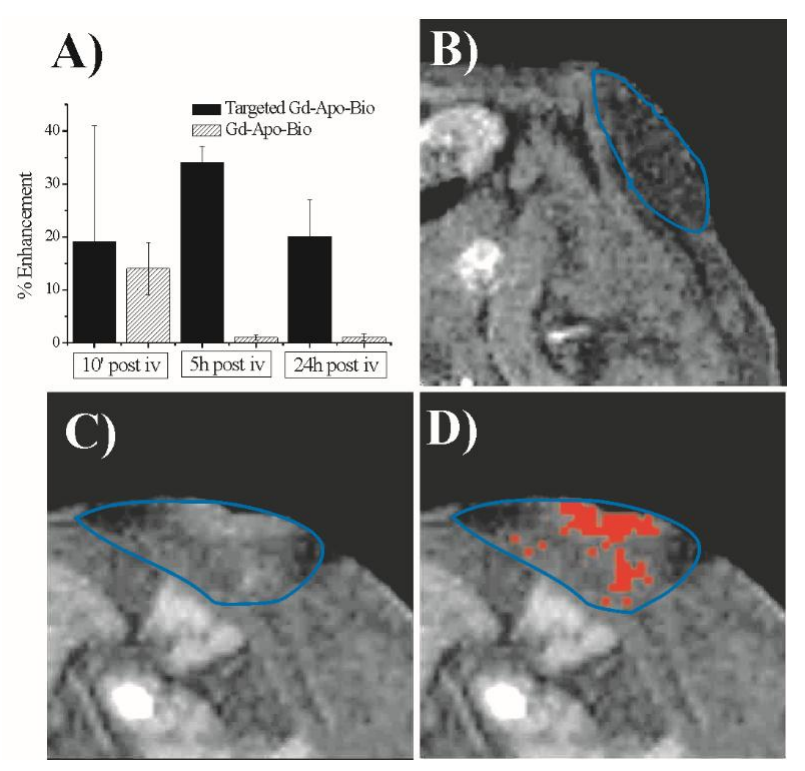

Figure 5. (A) MRI signal intensity (SI) enhancement of tumors in SCID mice grafted with TECs treated with Gd-loaded apoferritin targeted and nontargeted to N-CAMs. MR $\mathrm{T}_{1}$-weighted images of tumors done before (B) and $5 \mathrm{~h}$ after (C and D) administration of C3d-Bio/streptavidin/Gd-loaded apoferritin (20:1:1), which corresponds to a Gd dose of $0.01 \mathrm{mmol} / \mathrm{kg} 10$ times lower than that used in clinical protocols. The tumors are outlined in blue; red highlights the areas where the signal is 3 signal difference (SD) more intense than the precontrast tumor intensity (D). Reproduced with permission from [35]. Copyright American Association for Cancer Research, 2006. 


\section{Mn-Loaded Apoferritin}

Concerns over the relationship between Gd and nephrogenic systemic fibrosis and the increased risk of toxicity caused by $\mathrm{Gd}$ deposition in the brain are increasing efforts to develop alternative CAs that do not contain Gd [36]. Manganese(II) is a paramagnetic metal and may be considered a good candidate because it is an essential metal in biological systems, with efficient cellular storage/excretion routes for controlling its homeostasis. Unfortunately, when manganese is administrated intraveneously as $\mathrm{MnCl}_{2}$, it shows a low Lethal Dose $50\left(\mathrm{LD}_{50}\right)$ of $0.32 \mathrm{mmol} / \mathrm{kg}$ in mice [37]. An Mn-loaded HoS-apoferritin system (Mn-Apo) was proposed by Kalman et al. [38] to combine low toxicity with high efficacy. Following a previously reported procedure [39], MnOOH-loaded apoferritin was prepared by incubating the protein at $\mathrm{pH} 9$ in $\mathrm{MnCl}_{2}$ solution under air. After a week, a reduction/dissolution process was carried out by adding an excess of 1,4,8,11-tetraazacyclotetradecane-1,4,8,11-tetraacetic acid (TETA) ligand to eliminate Mn(II) ions from the protein shell outer surface and, at the same time, to partially dissolve nanosized $\beta-\mathrm{MnOOH}$ crystals trapped within the protein cavity via the reduction of $\mathrm{Mn}(\mathrm{III})$ to $\mathrm{Mn}(\mathrm{II})$ (Figure 6).

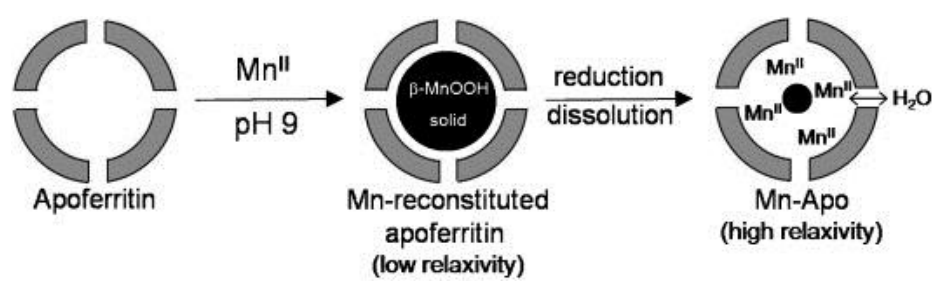

Figure 6. Mn-Apo preparation. Reproduced with permission from [38]. Copyright John Wiley and Sons, 2010.

Mn-Apo reached a very high $\mathrm{r}_{1}$ due to the presence of about $1090 \mathrm{Mn}$ atoms in the cavity, ca. $6.2 \pm 0.3 \mathrm{mM}^{-1} \mathrm{~s}^{-1}$ per $\mathrm{Mn}$ ion at $0.5 \mathrm{~T}$ and $25^{\circ} \mathrm{C}$ and in the range of ca. $4000-7000 \mathrm{mM}^{-1} \mathrm{~s}^{-1}$ per apoferritin molecule. This value is almost one order of magnitude higher with respect to Gd-HPDO3A-loaded apoferritin. The high sensitivity of Mn-Apo was exploited by Geninatti Crich et al. [40] to discriminate between hepatic dysplastic/neoplastic lesions and normal parenchyma in vitro and in an in vivo model of hepatocellular carcinoma (HCC) in hepatitis B virus (HBV) transgenic mice. The expression/regulation of SCARA5, that selectively internalizes L-ferritin in normal hepatocytes, was exploited to visualize hepatoma cells that conversely downregulate it on HBV transgenic (HBV-tg) mice. After administration of Mn-Apo, in the $\mathrm{T}_{1}$ weighted images of the liver recorded at 7T, it was possible to distinguish hypointense lesions with respect to hyperintense normal hepatic tissue. This interesting result was confirmed after $72 \mathrm{~h}$ by injecting a hepatotropic CA, Gd-gadobentatedimeglumine (Gd-BOPTA) into the same mice (Figure 2F), which is known to be well internalized by murine hepatocytes through organic anion transporting polypeptide (OATP) transporters (Figure 7).

The selective uptake of Mn-Apo through SCARA5 receptors was also investigated in human breast cancer cells, MCF7 and MDA-MB-231 [41]. The high expression of SCARA5 in MCF7 cells generated hyperintense signals in MR images (7T) with respect to MDA-MB-231 cells that display a lower expression. The longitudinal relaxation rate $1 / T_{1}=R_{1}\left(s^{-1}\right)$ increased proportionally for MCF7 cells, increasing the concentration of Mn-Apo added to the medium and remained low and constant for MDA-MB-231 cells. Moreover, Szabo et al. [42] demonstrated that Mn-OOH-loaded apoferritin can be used as a sensor of melanin formation in melanocytes. The oxidative process during melanin formation displayed suitable redox characteristics for which the involved reduced species may act as reductant agents for $\mathrm{Mn}(\mathrm{III})$ ions. The ability to reduce the $\mathrm{MnOOH}$ core was determined previously in an in vitro assay showing an increased Mn-Apo solution $\mathrm{R}_{1}$ (from 0.5 to $6 \mathrm{~s}^{-1}$ ) after the addition of L-3,4-dihydroxyphenylalanine (L-DOPA) and tyrosinase. Thereafter, the potential of Mn-Apo was assessed on melanogenic and non-melanogenic cells in in vitro and in vivo 
studies. Mn-Apo was able to discriminate between the two cell clones in MRI experiments, upon the incubation of $0.4 \mathrm{mM} \mathrm{MnOOH}-\mathrm{Apo}$ for $4 \mathrm{~h}$ at $37^{\circ} \mathrm{C}$. Similarly, when injected intratumorally in melanoma tumor-bearing mice, the $\mathrm{T}_{1}$-weighted $\mathrm{MR}$ images (1T) showed a marked SI enhancement in the tumor region but not in mice muscle, injected with the same dose, thus indicating the specificity of Mn-Apo as a MRI sensor of the melanine formation process [42]. Finally, another example of the use of apoferritin loaded with a $\mathrm{MnOOH}$ core was reported by Patrick et al. [43]. The TIM-2 receptor (T-cell immunoglobulin and mucin domain containing protein 2) that mediates H-ferritin endocytosis was exploited by the authors as an MRI-based gene reporter [43]. HEK 293T (human embryonic kidney) cells modified to express the TIM-2 transgene were incubated for 30 min in the presence of MnOOH-Apo. The HEK-293T-expressing TIM-2 cells showed an increased signal in the $\mathrm{T}_{1}$-weighted images and a decreased signal in $\mathrm{T}_{2}$-weighted images acquired at $7 \mathrm{~T}$, three-fold higher and two-fold lower in $\mathrm{R}_{1}$ and $\mathrm{R}_{2}$ compared to control cells, respectively. However, the effect of $\mathrm{MnOOH}-\mathrm{Apo}$ on cellular growth and viability limited its in vivo application. An alternative approach proposed by Sana et al. [44] was based on the use of an engineered A. fulgidus ferritin (AfFtn-AA), a tetracosameric ferritin known to form a tetrahedral cage presenting four openings (45 $\AA$ diameter). This protein exists as a dimer in low ionic strength buffer but in the presence of divalent metal ions, such as $\mathrm{MnCl}_{2}$, subunits self-assemble in a 24-meric protein cage. A total of $500 \mathrm{Mn}$ atoms were encapsulated per protein cage and the mineral core formation was detected by transmission electron microscopy (TEM). The longitudinal $r_{1}$ and transverse $r_{2}$ relaxivities were 10 and $74 \mathrm{mM}^{-1} \mathrm{~s}^{-1}(3 \mathrm{~T})$, respectively, equivalent to $6650 \mathrm{mM}^{-1} \mathrm{~s}^{-1}$ and $47,200 \mathrm{mM}^{-1} \mathrm{~s}^{-1}$ per apoferritin molecule.
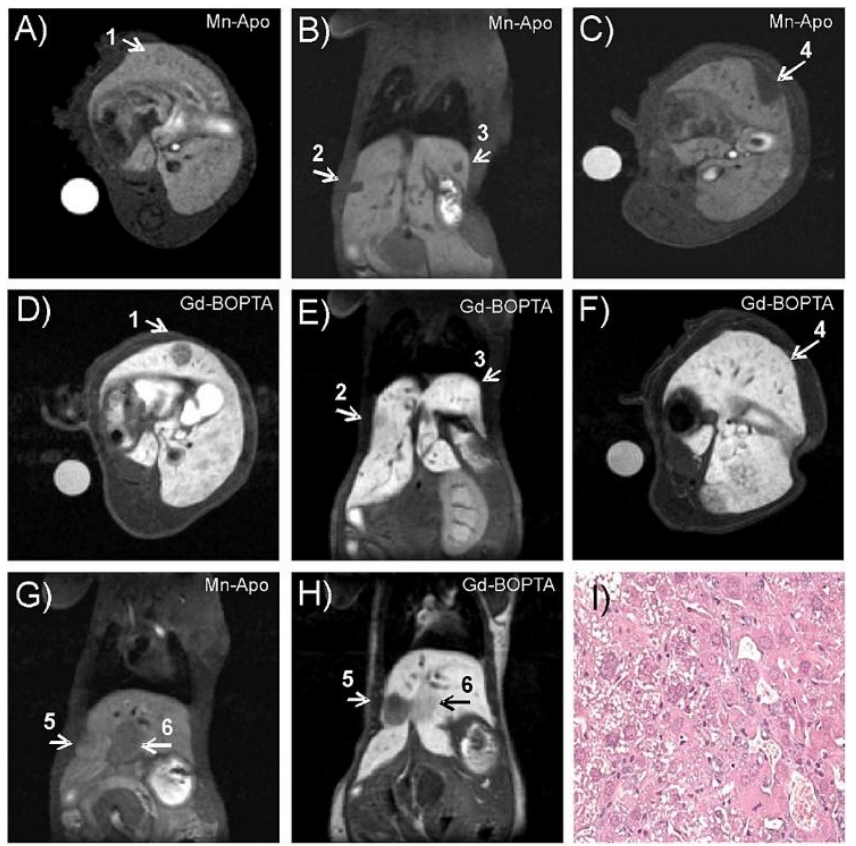

Figure 7. In vivo MRI on HBV-Tg mice. $\mathrm{T}_{1}$-weighted MR images (liver region), recorded at $7 \mathrm{~T}$, of HBV-Tg transgenic mice 20 min after the injection of Mn-Apo (A-C,G) and, after $72 \mathrm{~h}$ of Gd-BOPTA $(\mathrm{D}-\mathrm{F}, \mathbf{H})$, respectively. Neoplastic lesions were indicated by growing numbers. Lesions 1 and 5 were hypointense with respect to normal liver only after Gd-BOPTA administration, but lesions 3 and 4 only after Mn-Apo injection. Lesions 2 and 6 were hypointense with both CAs. (I) Hepatocelular carcinoma in a 13-month-old HBV-Tg transgenic mouse $(\times 200$ hematoxylin-eosin $)$. Reproduced with permission from [40]. Copyright John Wiley and Sons, 2012.

\section{Magnetoferritin}

Ferritin contains a superparamagnetic ferrihydrite crystal $\left(5 \mathrm{Fe}_{2} \mathrm{O}_{3} \cdot 9 \mathrm{H}_{2} \mathrm{O}\right)$ which increases the $\mathrm{R}_{2}$ of solvent water protons, causing a negative contrast in the corresponding images. In fact, the presence 
of ferritin within tissues influences the SI in $\mathrm{T}_{2}$-weighted MRI of the liver, spleen, and brain-the organs where ferritin concentration is highest $[45,46]$. The effect of ferritin on $\mathrm{MRI} \mathrm{T}_{2}$-contrast increases with the magnetic field strength. Water-soluble magnetic iron oxides, with a significantly higher sensitivity, which are coated with biocompatible polymers, have been used as highly sensitive MRI CAs in many preclinical and some clinical studies [47]. Depending on their size, they are called small or ultrasmall particle iron oxide (SPIO or USPIO) particles. They are taken up efficiently by the monocytes-macrophages system, so they are good candidates for the imaging of inflammation. Although two of the commercially available agents (endorem, and resovist) were withdrawn from the market mainly due to economic reasons and some side effects [48], SPIO and USPIO particles continue to be under preclinical investigation with the aim to improve their efficacy and safety. As ferritin is the final iron form after the degradation of these iron oxide particles [49], Valero et al. proposed to encapsulate the particles (of 4 and $6 \mathrm{~nm}$ ) directly in the protein cavity to prevent their degradation [50]. The $\mathrm{pH}$-driven horse spleen apoferritin disassembly/assembly protocol described above was used and the obtained loaded protein was called apomaghemite (APOMAG). Thereafter, the efficiency in generating $\mathrm{T}_{2}{ }^{*}$ contrast in MRI images was evaluated after their injection into mice. The contrast produced on $\mathrm{T}_{2}{ }^{*}$ images was very similar to that obtained after the injection of endorem (the SPIO commercially available reference particle). These results suggested that APOMAG samples are promising CAs. Moreover, APOMAG was functionalized with carbohydrate moieties (mannose and $\mathrm{N}$-acetyl glucosamine) on its external surface through binding to amine groups located at the external protein shell. The retention of the recognition abilities of the carbohydrate-functionalized APOMAG was demonstrated by measuring its strong affinity with the corresponding carbohydrate-binding lectins [50]. Moreover, Masaki et al. [51] proposed the use of a recombinant human H-chain ferritin (rHFn)-iron oxide nanocomposite as an MRI contrast agent for labeling macrophages. Magnetites or maghemites with narrow size distribution and low $\mathrm{T}_{2}{ }^{*}$ were synthesized in the interior cavity of rHFn. The mineralized protein cages were readily taken up by macrophages in vitro and provided significant $\mathrm{T}_{2}{ }^{*}$ signal loss of the labeled cells, encouraging further investigation to assess the inflammatory disease status such as macrophage-rich atherosclerotic plaques in vivo [51]. Recently, ultrafine H-ferritin-based iron oxide nanoparticles with hematite and/or maghemite cores (diameters $<5 \mathrm{~nm}$ ) were proposed by Yao et al. [52] as positive CAs for magnetic resonance angiography (MRA). The ferritin nanoparticles with a higher $r_{1}$ value and lower $r_{2} / r_{1}$ ratio were selected for MRA experiments. High spatial resolution steady-state images of the vascular compartment were obtained from $3 \mathrm{~min}$ up to $2 \mathrm{~h}$ after a single injection of these nanoprobes, mainly due to the long-term blood pool imaging. The single injection and long-term imaging feature suggest their obvious advantages in MRA application compared with other small-sized Gd-based CAs [52].

\section{Ferritin as an Endogenous MRI Reporter for Gene Expression Imaging}

Reporter genes allow the noninvasive study of the dynamics of gene expression and can be exploited as helpful tools to validate the efficacy of gene therapy and to monitor cell fate during treatment. Classical reporter genes code for fluorescent proteins, such as Green Fluorescent Protein (GFP) and enzymes that convert substrates into luminescent or colored products such as firefly luciferase. Therefore, optical imaging represents the main tool to monitor gene expression in vivo. One of the major drawbacks of this technique is the limited resolution and sensitivity caused by the depth of penetration and scattering of light. Instead, MRI could represent the ideal technique to monitor gene expression, due to its high spatial resolution, tissue penetration and contrast. Ferritin was suggested as a candidate endogenous reporter gene for the in vivo imaging of gene expression [53]. In particular, the induced expression of ferritin leads to a transient decrease in the iron content of the cell, which is physiologically balanced by the subsequent increase in the expression of iron importers, such as TfR-1 [53]. This leads to a net accumulation of iron inside the cell, which can be safely allocated inside ferritin. The accumulation and redistribution of iron alter MR relaxation rates, causing a negative contrast. The use of ferritin as gene expression reporter has been mainly exploited to study tumor 
biology and to follow the fate of stem cell grafts. Cohen and coworkers [54] designed a multimodal reporter gene where ferritin H-chain and the enhanced green fluorescent protein (EGFP) expression was controlled by tetracycline (TET) in C6 rat glioma cells. When ferritin was overexpressed in the absence of TET, $r_{2}$ significantly increased which allowed the tumor growth course to be followed [54]. In tumor biology, the ferritin reporter gene has also been used to visualize the recruitment of fibroblasts from local or remote tissue to the angiogenic rim of tumors [55]. Vandsburger et al. [55] demonstrated that ferritin heavy chain overexpression in monkey kidney cell line (CV1) fibroblasts enhanced iron uptake and retention, causing a detectable contrast in $\mathrm{T}_{2}{ }^{*}$-weighted MR images. $\mathrm{r}_{2}$ mapping also revealed the spatiotemporal kinetics of fibroblast recruitment even at low cellular densities, allowing the characterization of the dynamics of the tumor microenvironment.

The imaging of stem cells is important to monitor their delivery, fate and function after transplantation in the host environment. One critical issue is to be able to distinguish between live and dead cells after the graft. Direct labeling of stem cells, which consists of the loading of cells with contrast agents prior to the engraftment, shows some limitations: asymmetric dilution of the probe with cellular proliferation, persistence of label after cell death, indirect relationship between signal intensity changes and total number of labeled cells [56]. The use of an endogenous reporter gene, which is integrated into the genome and continuously expressed, is particularly convenient to avoid these problems. Iordanova et al. used primary neuronal progenitors expressing a chimeric ferritin molecule $\left(\mathrm{L}^{*} \mathrm{H}\right)$ to visualize in the mouse brain their migration from the sub ventricular zone (SVZ) to the olfactory bulb. The $\mathrm{L}^{*} \mathrm{H}$ showed higher iron loading and significantly higher MRI contrast enhancement compared to wild-type ferritin, allowing the detection of cell clusters of the order of $10^{4}$ cells [57]. They [58] induced ferritin heavy chain (FTH1) expression by using a Tet-On switch in the C3H10T1/2 cell line. The expression was dose- and time-dependent upon Doxorubicin administration [58]. Recently, Dai et al. showed that ferritin overexpression through the exogenous rAdV-mediated FTH1 gene in bone marrow mesenchymal stem cells (BMSCs) resulted in a decrease in $\mathrm{T}_{2}$ signals acquired at 7T [59]. Zhang et al. [60] transfected neuronal stem cells (NSCs) with a lentiviral vector carrying both MRI and the fluorescence-imaging reporter gene. MRI and fluorescence imaging were used to monitor the fate of NSCs after transplantation in rat striatum after acute ischemic stroke over a long period of time [60]. The use of an endogenous reporter gene is also particularly convenient to overcome problems related to crossing delivery barriers (i.e., the blood-brain barrier) or short residence times of contrast agents. This can be particularly useful in neuroscience to study cognitive processes and complex behaviors. Wu and coworkers [61] generated transgenic mice expressing ferritin heavy chain and the mKate2 fusion protein reporter gene under the Arc promoter, which is induced in mammalian brain by increased neuronal activity. After treatment with pilocarpine, a non-selective muscarinic agonist, an increase in $\mathrm{T}_{2}$-weighted image signal was observed in neurons of the hippocampal and cortex regions [61].

\section{Theranostic Use of Ferritin}

Personalized medicine is one of major expectations of nanomedicine, enabling diagnostics and therapeutics to target individual needs and developing a truly "patient-friendly" medical approach [62]. At the same time, the rapidly evolving field of molecular imaging promises improvements in patient screening and early diagnosis $[63,64]$. The combination of diagnostic and therapeutic agents within a single formulation (i.e., dendrimers, micelles, liposomes, metallic and inorganic nanoparticles, carbon nanotubes), provides real-time feedback on the pharmacokinetics, the target site localization and the (off-target) healthy organ drug accumulation $[65,66]$. In this context, protein-based nanocages are a good candidate as potential devices for theranostics purposes. In particular, ferritin, due to properties such as its high stability and biocompatibility, has emerged also as an excellent and promising drug carrier [67]. Although Doxorubicin encapsulation in ferritin nanocages represents the most extensively investigated system $[29,68,69]$, there are also some interesting results reporting the efficacy of the encapsulated Cisplatin [70-72]. Several studies have provided strong evidence of an enhanced efficacy 
of chemotherapeutic therapy after their encapsulation in ferritin-based nanoparticles, not only for anticancer drugs, but also for other active molecules [29]. The first example of the use of apoferritin to deliver therapeutic and imaging agents simultaneously was proposed to target hepatocytes by SCARA5 via the ferritin-transporting route [73]. Gd-HPDO3A (Figure 2C) and Curcumin, a polyphenolic substance endowed with multiple pharmacological actions (namely, antioxidant, anti-inflammatory, antineoplastic), have been loaded using the $\mathrm{pH}$-based disassembling/reassembling protocol. The theranostic efficiency of Curcumin and Gd-HPDO3A-loaded apoferritin (Apo-CUR-Gd) has been validated on thioacetamide-induced hepatitis. Mice pre-treated with intraperitoneal administration of Apo-CUR-Gd showed significantly attenuated hepatic injury as assessed by measuring alanine aminotransferase (ALT) activity in plasma and by histological assessment. The encapsulation of Curcumin inside the apoferritin cavity significantly increases its stability and bioavailability while maintaining its therapeutic anti-inflammatory properties [73]. More recently, the theranostic potential of Apo-CUR-Gd was assessed on cancer stem cells (CSCs) [74]. Most evidence suggests that CSCs have the unique biological properties necessary for tumor maintenance and spreading, and function as a reservoir for the relapse and metastatic evolution of the disease by virtue of their resistance to radio- and chemo-therapies [75]. The CSC-enriched tumorspheres from breast cancer cell lines display an increased L-ferritin uptake capability compared to their monolayer counterparts as a consequence of the upregulation of the L-ferritin receptor SCARA5 [74]. This theranostic system was able to impair the viability and self-renewal of tumorspheres in vitro and to induce the regression of established tumors in mice. Apo-CUR-Gd not only has strong therapeutic potential due to specific targeting but also the advantage of improved Curcumin bioavailability. Moreover, a completely different approach was used by Ruggiero et al. [76] for theranostic purposes. Polylactic and glycolic acid nanoparticles (PLGA-NPs), coated with L-ferritin, were exploited for the simultaneous delivery of paclitaxel (PTX) and an amphiphilic Gd(III)-based MRI contrast agent into human breast cancer cells (MCF7). Exploiting N-hydroxysuccinimide (NHS) activated carboxylic groups, L-ferritin was covalently conjugated to the external surface of PLGA-NPs. The results confirmed that ferritin-nanoparticles have many therapeutic advantages with respect to both albumin-decorated and non-decorated particles and the injectable formulation of the drug (Paclitaxel Kabi), especially at short incubation time. Ferritin moieties endow PLGA-NPs with targeting capability, exploiting SCARA5 receptors overexpressed by most cancer cells, which results in an increased paclitaxel cytotoxicity in comparison to the clinically used formulation. Moreover, protein coating increased nanoparticle stability, thus reducing the fast and unspecific drug release of this kind of nanosystem before delivery to the target site. The specificity of this theranostic nanoparticle has been demonstrated by evaluating the signal intensity enhancement on the $\mathrm{T}_{1}$-weighted MRI images of labeled MCF7 cells, compared to MDA-MB 231 breast cancer cells used as negative control due to their lower SCARA5 expression [76]. Finally, Cutrin et al. [77] proposed iron-loaded H- and HoS- (Horse Spleen, containing 85\% of L subunits) ferritins as natural nano-theranostic agents exploiting their ability to deliver iron into epitheloid cervix carcinoma (HeLa) cells expressing both TfR-1 and SCARA5 receptors, allowing $\mathrm{H}$ - and L-cage internalization, respectively. It was reported that iron starvation can damage cell development and growth, whereas excessive iron accumulation leads to cytotoxicity, through the over-production of free radicals. Moreover, tumor cells appear unable to properly manage iron excess removal, basically, as a consequence of ferritin downregulation observed in many human cancers [78]. Both H- and HoS-ferritins showed high cytotoxicity in HeLa cells but very different cell death profiles [77]. The higher H-ferritin toxicity in cells resulted in a submicromolar concentration for the presence of a pool of non-biomineralized iron ions bound at the ferroxidase catalytic sites, absent in HoS-ferritins, that was readily released during the endosomal-mediated internalization. Moreover, due to the ability of the iron core in ferritin to act as a negative MRI contrast agent, ferritins can be proposed as natural theranostic agents that do not need any further modifications. The amount of $\mathrm{H}$ - and HoS-ferritins taken-up by HeLa was enough to be detected by $\mathrm{T}_{2}$-weighted MRI experiments after $24 \mathrm{~h}$ incubation in the presence of $0.38 \mathrm{mM}$ iron-loaded ferritins (Figure 8). As expected, cells 
labeled with HoS-ferritin loaded with a more pronounced iron oxide core (1000 Fe atoms) are more hypointense than those labeled with H-ferritin (350 Fe atoms).

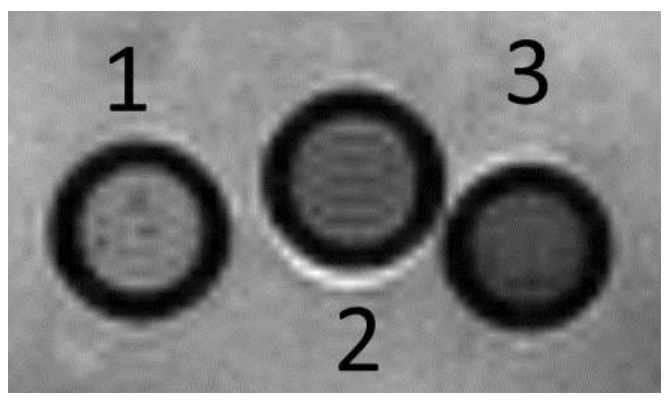

Figure 8. A $T_{2}$-weighted RARE MR image recorded at $7 \mathrm{~T}$ of agar phantoms containing (1) HeLa cells; (2) Hela incubated for $24 \mathrm{~h}$ with H-ferritin (2) and HoS-ferritin (3). Unpublished data.

\section{Conclusions}

Ferritin is one of the most commonly used proteins in preclinical MRI applications, as demonstrated by the large volume of literature dedicated to its use for CA delivery. In fact, due to its high versatility, the protein's internal cavity can be exploited for both the mineralization of paramagnetic metals $\left(\mathrm{Fe}, \mathrm{Gd}^{3+}, \mathrm{Mn}^{2+}\right)$ and the delivery of $\mathrm{Gd}$-complexes and other biologically active molecules. Moreover, the internal surface of the protein core plays an active role in enhancing the relaxivities of internalized CA. Finally, the ferritin gene can be exploited as a gene expression reporter due to the presence of its natural iron core that can be used to modulate signal intensity in $\mathrm{T}_{2}$-weighted image protocols.

Funding: This research was funded by the European Union Horizon2020 research and innovation programme under grant agreement No 668119 (project"IDentIFY"), by the Italian Ministry for Education and Research (MIUR) that funded the Euro-BioImaging Multi-Modal Molecular Imaging Italian Node (MMMI) and by COST Action AC15209 (EURELAX), supported by COST (European Cooperation in Science and Technology).

Conflicts of Interest: The authors declare no conflict of interest.

\section{References}

1. Wahsner, J.; Gale, E.M.; Rodríguez-Rodríguez, A.; Caravan, P. Chemistry of MRI Contrast Agents: Current Challenges and New Frontiers. Chem. Rev. 2018. [CrossRef] [PubMed]

2. Terreno, E.; Dastrù, W.; Delli Castelli, D.; Gianolio, E.; Geninatti Crich, S.; Longo, D.; Aime, S. Advances in metal-based probes for MR molecular imaging applications. Curr. Med. Chem. 2010, 17, 3684-3700. [CrossRef] [PubMed]

3. Bonnet, C.S.; Tóth, E. MRI probes for sensing biologically relevant metal ions. Future Med. Chem. 2010, 2, 367-384. [CrossRef] [PubMed]

4. Fasano, M.; Curry, S.; Terreno, E.; Galliano, M.; Fanali, G.; Narciso, P.; Notari, S.; Ascenzi, P. The extraordinary ligand binding properties of human serum albumin. IUBMB Life 2005, 57, 787-796. [CrossRef] [PubMed]

5. Longo, D.L.; Arena, F.; Consolino, L.; Minazzi, P.; Geninatti-Crich, S.; Giovenzana, G.B.; Aime, S. Gd-AAZTA-MADEC, an improved blood pool agent for DCE-MRI studies on mice on $1 \mathrm{~T}$ scanners. Biomaterials 2016, 75, 47-57. [CrossRef] [PubMed]

6. Thaxton, C.S.; Rink, J.S.; Naha, P.C.; Cormode, D.P. Lipoproteins and lipoprotein mimetics for imaging and drug delivery. Adv. Drug Deliv. Rev. 2016, 106, 116-131. [CrossRef] [PubMed]

7. Geninatti Crich, S.; Alberti, D.; Szabo, I.; Deagostino, A.; Toppino, A.; Barge, A.; Ballarini, F.; Bortolussi, S.; Bruschi, P.; Protti, N.; et al. MRI-guided neutron capture therapy by use of a dual gadolinium/boron agent targeted at tumour cells through upregulated low-density lipoprotein transporters. Chem. Eur. J. 2011, 17, 8479-8486. [CrossRef] [PubMed]

8. Arosio, P.; Ingrassia, R.; Cavadini, P. Ferritins: A family of molecules for iron storage, antioxidation and more. Biochim. Biophys. Acta 2009, 1790, 589-599. [CrossRef] [PubMed] 
9. Chiou, B.; Connor, J.R. Emerging and Dynamic Biomedical Uses of Ferritin. Pharmaceuticals 2018, 11, 124. [CrossRef] [PubMed]

10. Jutz, G.; van Rijn, P.; Santos, M.B.; Böker, A.P. Ferritin: A versatile building block for bionanotechnology. Chem. Rev. 2015, 115, 1653-1701. [CrossRef] [PubMed]

11. Theil, E.C. Ferritin: The protein nanocage and iron biomineral in health and in disease. Inorg. Chem. 2013, 52, 12223-12233. [CrossRef] [PubMed]

12. Todorich, B.; Zhang, X.; Connor, J.R. H-ferritin is the major source of iron for oligodendrocytes. Glia 2011, 59, 927-935. [CrossRef] [PubMed]

13. Adams, P.C.; Chau, L.A. Uptake of ferritin by isolated rat hepatocytes. Effect of metabolic inhibitors and iron. Clin. Investig. Med. Méd. Clin. Exp. 1993, 16, 15-21.

14. Blight, G.D.; Morgan, E.H. Ferritin and iron uptake by reticulocytes. Br. J. Haematol. 1983, 55, 59-71. [CrossRef] [PubMed]

15. Moss, D.; Powell, L.W.; Arosio, P.; Halliday, J.W. Characterization of the ferritin receptors of human T lymphoid (MOLT-4) cells. J. Lab. Clin. Med. 1992, 119, 273-279. [PubMed]

16. Sakamoto, S.; Kawabata, H.; Masuda, T.; Uchiyama, T.; Mizumoto, C.; Ohmori, K.; Koeffler, H.P.; Kadowaki, N.; Takaori-KondoH, A. H-Ferritin is Preferentially Incorporated by Human Erythroid Cells through Transferrin Receptor 1 in a Threshold-Dependent Manner. PLoS ONE 2015, 10, e0139915. [CrossRef] [PubMed]

17. Li, J.Y.; Paragas, N.; Ned, R.M.; Qiu, A.; Viltard, M.; Leete, T.; Drexler, I.R.; Chen, X.; Sanna-Cherchi, S.; Mohammed, F.; et al. Scara5 is a ferritin receptor mediating non-transferrin iron delivery. Dev. Cell 2009, 16, 35-46. [CrossRef] [PubMed]

18. Han, J.; Seaman, W.E.; Di, X.; Wang, W.; Willingham, M.; Torti, F.M.; Torti, S.V. Iron uptake mediated by binding of H-ferritin to the TIM-2 receptor in mouse cells. PLOS ONE 2011, 6, e23800. [CrossRef] [PubMed]

19. Li, L.; Fang, J.C.; Ryan, J.C.; Niemi, E.C.; Lebrón, J.A.; Björkman, P.J.; Arase, H.; Torti, F.M.; Torti, S.V.; Nakamura, M.C.; et al. Binding and uptake of H-ferritin are mediated by human transferrin receptor-1. Proc. Natl. Acad. Sci. USA 2010, 107, 3505-3510. [CrossRef] [PubMed]

20. Li, L.; Zhang, L.; Knez, M. Comparison of two endogenous delivery agents in cancer therapy: Exosomes and ferritin. Pharmacol. Res. 2016, 110, 1-9. [CrossRef] [PubMed]

21. Knovich, M.A.; Storey, J.A.; Coffman, L.G.; Torti, S.V. Ferritin for the Clinician. Blood Rev. 2009, 23, 95-104. [CrossRef] [PubMed]

22. Shen, Y.; Li, X.; Dong, D.; Zhang, B.; Xue, Y.; Shang, P. Transferrin receptor 1 in cancer: A new sight for cancer therapy. Am. J. Cancer Res. 2018, 8, 916-931. [PubMed]

23. Huang, J.; Zheng, D.L.; Qin, F.S.; Cheng, N.; Chen, H.; Wan, B.B.; Wang, Y.P.; Xiao, H.S.; Han, Z.G. Genetic and epigenetic silencing of SCARA 5 may contribute to human hepatocellular carcinoma by activating FAK signaling. J. Clin. Investig. 2010, 120, 223-241. [CrossRef] [PubMed]

24. You, K.; Su, F.; Liu, L.; Lv, X.; Zhang, J.; Zhang, Y.; Liu, B. SCARA5 plays a critical role in the progression and metastasis of breast cancer by inactivating the ERK1/2, STAT3, and AKT signaling pathways. Mol. Cell Biochem. 2017, 435, 47-58. [CrossRef] [PubMed]

25. Khoshnejad, M.; Parhiza, H.; Shuvaeva, V.V.; Dmochowskib, I.J.; Muzykantova, V.R. Ferritin-based drug delivery systems: Hybrid nanocarriers for vascular immunotargeting. J. Control. Release 2018, 282, $13-24$. [CrossRef] [PubMed]

26. Khoshnejad, M.; Greineder, C.F.; Pulsipher, K.W.; Villa, C.H.; Altun, B.; Pan, D.C.; Tsourkas, A.; Dmochowski, I.J.; Muzykantov, V.R. Ferritin Nanocages with Biologically Orthogonal Conjugation for Vascular Targeting and Imaging. Bioconj. Chem. 2018, 29, 1209-1218. [CrossRef] [PubMed]

27. Aime, S.; Cabella, C.; Colombatto, S.; Geninatti Crich, S.; Gianolio, E.; Maggioni, F. Insights into the use of paramagnetic Gd(III) complexes in MR-molecular imaging investigations. J. Magn. Reson. Imaging 2002, 16, 394-406. [CrossRef] [PubMed]

28. Yang, X.; Chasteen, N.D. Molecular diffusion into horse spleen ferritin: A nitroxide radical spin probe study. Biophys. J. 1996, 71, 1587-1595. [CrossRef]

29. Belletti, D.; Pederzoli, F.; Forni, F.; Vandelli, M.A.; Tosi, G.; Ruozi, B. Protein cage nanostructure as drug delivery system: Magnifying glass on apoferritin. Expert Opin. Drug Deliv. 2017, 14, 825-840. [CrossRef] [PubMed] 
30. Aime, S.; Frullano, L.; Geninatti Crich, S. Compartmentalization of a gadolinium complex in the apoferritin cavity: A route to obtain high relaxivity contrast agents for magnetic resonance imaging. Angew. Chem. Int. Ed. Engl. 2002, 41, 1017-1019. [CrossRef]

31. Vasalatiy, O.; Zhao, P.; Zhang, S.; Aime, S.; Sherry, A.D. Catalytic effects of apoferritin interior surface residues on water proton exchange in lanthanide complexes. Contrast Media Mol. Imaging 2006, 1, $10-14$. [CrossRef] [PubMed]

32. Fries, P.H.; Belorizky, E. Enhancement of the water proton relaxivity by trapping $\mathrm{Gd}^{3+}$ complexes in nanovesicles. J. Chem. Phys. 2010, 133, 024504. [CrossRef] [PubMed]

33. Makino, A.; Harada, H.; Okada, T.; Kimura, H.; Amano, H.; Saji, H.; Hiraoka, M.; Kimura, S. Effective encapsulation of a new cationic gadolinium chelates into apoferritin and its evaluation as an MRI contrast agent. Nanomedicine 2011, 7, 638-646. [CrossRef] [PubMed]

34. Sánchez, P.; Valero, E.; Gálvez, N.; Domínguez-Vera, J.M.; Marinone, M.; Poletti, G.; Corti, M.; Lascialfari, A. MRI relaxation properties of water-soluble apoferritin-encapsulated gadolinium oxide-hydroxide nanoparticles. Dalton Trans. 2009, 5, 800-804. [CrossRef] [PubMed]

35. Geninatti Crich, S.; Bussolati, B.; Tei, L.; Grange, C.; Esposito, G.; Lanzardo, S.; Camussi, G.; Aime, S. Magnetic resonance visualization of tumor angiogenesis by targeting neural cell adhesion molecules with the highly sensitive gadolinium-loaded apoferritin probe. Cancer Res. 2006, 66, 9196-9201. [CrossRef] [PubMed]

36. Thakral, C.; Alhariri, J.; Abraham, J.L. Long-term retention of gadolinium in tissues from nephrogenic systemic fibrosis patient after multiple gadolinium-enhanced MRI scans: Case report and implications. Contrast Media Mol. Imaging 2007, 2, 199-205. [CrossRef] [PubMed]

37. Pan, D.; Caruthers, S.D.; Senpan, A.; Schmieder, A.H.; Wickline, S.A.; Lanza, G.M. Revisiting an old friend: Manganese-based MRI contrast agents. Wiley Interdiscip. Rev. Nanomed. Nanobiotechnol. 2011, 3, 162-173. [CrossRef] [PubMed]

38. Kálmán, F.K.; Geninatti-Crich, S.; Aime, S. Reduction/dissolution of a beta-MnOOH nanophase in the ferritin cavity to yield a highly sensitive, biologically compatible magnetic resonance imaging agent. Angew. Chem. Int. Ed. Engl. 2010, 49, 612-615. [CrossRef] [PubMed]

39. Meldrum, F.C.; Douglas, T.; Levi, S.; Arosio, P.; Mann, S. Reconstitution of manganese oxide cores in horse spleen and recombinant ferritins. J. Inorg. Biochem. 1995, 58, 59-68. [CrossRef]

40. Geninatti Crich, S.; Cutrin, J.C.; Lanzardo, S.; Conti, L.; Kálmán, F.K.; Szabó, I.; Lago, N.R.; Iolascon, A.; Aime, S. Mn-loaded apoferritin: A highly sensitive MRI imaging probe for the detection and characterization of hepatocarcinoma lesions in a transgenic mouse model. Contrast Media Mol. Imaging 2012, 7, 281-288. [CrossRef] [PubMed]

41. Geninatti Crich, S.; Cadenazzi, M.; Lanzardo, S.; Conti, L.; Ruiu, R.; Alberti, D.; Cavallo, F.; Cutrin, J.C.; Aime, S. Targeting ferritin receptors for the selective delivery of imaging and therapeutic agents to breast cancer cells. Nanoscale 2015, 7, 6527-6533. [CrossRef] [PubMed]

42. Szabó, I.; Geninatti Crich, S.; Alberti, D.; Kálmán, F.K.; Aime, S. Mn loaded apoferritin as an MRI sensor of melanin formation in melanoma cells. Chem. Commun. (Camb.) 2012, 48, 2436-2438. [CrossRef] [PubMed]

43. Patrick, P.S.; Rodrigues, T.B.; Kettunen, M.I.; Lyons, S.K.; Neves, A.A.; Brindle, K.M. Development of Timd2 as a reporter gene for MRI. Magn. Reson. Med. 2016, 75, 1697-1707. [CrossRef] [PubMed]

44. Sana, B.; Poh, C.L.; Lim, S. A manganese-ferritin nanocomposite as an ultrasensitive $\mathrm{T}_{2}$ contrast agent. Chem. Commun. (Camb.) 2012, 48, 862-864. [CrossRef] [PubMed]

45. Hocq, A.; Luhmer, M.; Saussez, S.; Louryan, S.; Gillis, P.; Gossuin, Y. Effect of magnetic field and iron content on NMR proton relaxation of liver, spleen and brain tissues. Contrast Media Mol. Imaging 2014, 10, 144-152. [CrossRef] [PubMed]

46. Gossuin, Y.; Muller, R.N.; Gillis, P.; Bartel, L. Relaxivities of human liver and spleen ferritin. Magn. Reson. Imaging 2005, 23, 1001-1004. [CrossRef] [PubMed]

47. Laurent, S.; Forge, D.; Port, M.; Roch, A.; Robic, C.; Vander Elst, L.; Muller, R.N. Magnetic iron oxide nanoparticles: Synthesis, stabilization, vectorization, physicochemical characterizations, and biological applications. Chem. Rev. 2008, 108, 2064-2110. [CrossRef] [PubMed]

48. Unterweger, H.; Dézsi, L.; Matuszak, J.; Janko, C.; Poettler, M.; Jordan, J.; Bäuerle, T.; Szebeni, J.; Fey, T.; Boccaccini, A.; et al. Dextran-coated superparamagnetic iron oxide nanoparticles for magnetic resonance imaging: Evaluation of size-dependent imaging properties, storage stability and safety. Int. J. Nanomed. 2018, 13, 1899-1915. [CrossRef] [PubMed] 
49. López-Castro, J.D.; Maraloiu, A.V.; Delgado, J.J.; Calvino, J.J.; Blanchin, M.G.; Gálvez, N.; Domínguez-Vera, J.M. From synthetic to natural nanoparticle: Monitoring the biodegradation of SPIO into ferritin by electron microscopy. Nanoscale 2011, 3, 4597-4599. [CrossRef] [PubMed]

50. Valero, E.; Tambalo, S.; Marzola, P.; Ortega-Muñoz, M.; López-Jaramillo, F.J.; Santoyo-González, F.; de Dios López, J.; Delgado, J.J.; Calvino, J.J.; Cuesta, R.; et al. Magnetic Nanoparticles-Templated Assembly of Protein Subunits: A New Platform for Carbohydrate-Based MRI. Nanoprobes J. Am. Chem. Soc. 2011, 133, 4889-4895. [CrossRef] [PubMed]

51. Masaki, U.; Masahiro, T.; Cunningham, C.H.; Suzuki, Y.; Willits, D.A.; Willis, A.F.; Yang, P.C.; Tsao, P.S.; McConnell, M.C.; Young, M.J.; et al. A Human Ferritin Iron Oxide Nano-composite Magnetic Resonance Contrast Agent. Magn. Reson. Med. 2008, 60, 1073-1081.

52. Cai, Y.; Wang, Y.; Xua, H.; Cao, C.; Zhue, R.; Tang, X.; Zhang, T.; Pan, Y. Positive Magnetic Resonance Angiography by Ultrafine Ferritin-based Iron Oxide Nanoparticles. Nanoscale 2018. [CrossRef] [PubMed]

53. Cohen, B.; Ziv, K.; Plaks, V.; Harmelin, A.; Neeman, M. Ferritin nanoparticles as magnetic resonance reporter gene. Nanomed. Nanobiotechnol. 2009, 1, 181-188. [CrossRef] [PubMed]

54. Cohen, B.; Dafni, H.; Meir, G.; Harmelin, A.; Neeman, M. Ferritin as an endogenous MRI reporter for noninvasive imaging of gene expression in C6 glioma tumors. Neoplasia 2005, 7, 109-117. [CrossRef] [PubMed]

55. Vandsburger, M.H.; Radoul, M.; addadi, Y.; Mpofu, S.; Cohen, B.; Eliam, R.; Neeman, M. Quantitative bioexponential MR imaging relaxometry reveals the dynamic recruitment of ferritin-expressing fibroblasts to the angiogenic rim of tumors. Radiology 2013, 268, 790-801. [CrossRef] [PubMed]

56. Andrzejewska, A.; Nowakowski, A.; Janowski, M.; Bulte, J.W.; Gilad, A.A.; Walczak, P.; Lukomska, B. Preand postmortem imaging of transplanted cells. Int. J. Nanomed. 2015, 10, 5543-5559.

57. Iordanova, B.; Ahrens, E.T. In vivo magnetic resonance imaging of ferritin-based reporter visualizes native neuroblast migration. Neuroimage 2012, 59, 1004-1012. [CrossRef] [PubMed]

58. He, X.; Cai, J.; Liu, B.; Zhong, Y.; Qin, Y. Cellular magnetic resonance imaging contrast generated by the ferritin heavy chain genetic reporter under the control of a Tet-On switch. Stem Cell Res. Ther. 2015, 6, 1-11. [CrossRef] [PubMed]

59. Dai, H.; He, R.; Zhang, Y.; Wu, R.; Xiao, Y. Adenoviral vector mediated ferritin over-expression in mesenchymal stem cells detected by 7T MRI in vitro. PLoS ONE 2017, 12, e0185260. [CrossRef] [PubMed]

60. Zhang, F.; Duan, X.; Lu, L.; Zhang, X.; Chen, M.; Mao, J.; Cao, M.; Shen, J. In vivo long-term tracking of neuronal stem cells transplanted into an acute ischemic stroke model with reporter gene-based bimodal MR and optical imaging. Cell Transp. 2017, 26, 1648-1662. [CrossRef] [PubMed]

61. Wu, Q.; Ono, K.; Suzuki, H.; Eguchi, M.; Yamaguchi, S.; Sawada, M. Visualization of Arc promoter-driven neuronal activity by magnetic resonance imaging. Neurosci. Lett. 2017, 666, 92-97. [CrossRef] [PubMed]

62. Noury, M.; Lopez, J. Nanomedicine and personalised medicine: Understanding the personalisation of health care in the molecular era. Sociol. Health Illn. 2016, 20, 1-19. [CrossRef] [PubMed]

63. Mankoff, D.A. A definition of Molecular Imaging. J. Nucl. Med. 2007, 48, 18-21.

64. Lammers, T.; Aime, S.; Hennink, W.E.; Storm, G.; Kiessling, F. Theranostic Nanomedicine. Acc. Chem. Res. 2011, 44, 1029-1038. [CrossRef] [PubMed]

65. Caruthers, S.D.; Wickline, S.A.; Lanza, G.M. Nanotechnological applications in medicine. Curr. Opin. Biotechnol. 2007, 18, 26-30. [CrossRef] [PubMed]

66. Lammers, T.; Hennink, W.E.; Storm, G. Tumour-targeted nanomedicines: Principles and practice. Br. J. Cancer 2008, 99, 392-397. [CrossRef] [PubMed]

67. Truffi, M.; Fiandra, L.; Sorrentino, L.; Monieri, M.; Corsi, F.; Mazzucchelli, S. Ferritin nanocages: A biological platform for drug delivery, imaging and theranostics in cancer. Pharmacol. Res. 2016, 107, 57-65. [CrossRef] [PubMed]

68. Mazzucchelli, S.; Mazzucchelli, S.; Bellini, M.; Fiandra, L.; Truffi, M.; Rizzuto, M.A.; Sorrentino, L.; Longhi, E.; Nebuloni, M.; Prosperi, D.; et al. Nanometronomic treatment of 4T1 breast cancer with nanocaged doxorubicin prevents drug resistance and circumvents cardiotoxicity. Oncotarget 2017, 8, 8383-8396. [CrossRef] [PubMed]

69. Zheng, Z.; Tang, W.; Chen, H.; Lin, X.; Todd, T.; Wang, G.; Cowger, T.; Chen, X.; Xie, J. RGD-modified nanoparticles for efficient drug delivery to tumors. ACS Nano 2013, 7, 4830-4837. [CrossRef] [PubMed] 
70. Yang, Z.; Wang, X.; Diao, H.; Zhang, J.; Li, H.; Sun, H.; Guo, Z. Encapsulation of platinum anticancer drugs by apoferritin. Chem. Commun. 2007, 33, 3453-3455. [CrossRef] [PubMed]

71. Falvo, E.; Tremante, E.; Fraioli, R.; Leonetti, C.; Zamparelli, C.; Boffi, A.; Morea, V.; Ceci, P.; Giacomini, P. Antibody-drug conjugates: Targeting melanoma with cisplatin encapsulated in protein-cage nanoparticles based on human ferritin. Nanoscale 2013, 5, 12278-12285. [CrossRef] [PubMed]

72. Ferraro, G.; Pica, A.; Petruk, G.; Pane, F.; Amoresano, A.; Cilibrizzi, A.; Vilar, R.; Monti, D.M.; Merlino, A. Preparation, structure, cytotoxicity and mechanism of action of ferritin- $\mathrm{Pt}(\mathrm{II})$ terpyridine compound nanocomposites. Nanomedicine (Lond.) 2018. [CrossRef] [PubMed]

73. Cutrin, J.C.; Geninatti Crich, S.; Burghelea, D.; Dastrù, W.; Aime, S. Curcumin/Gd Loaded Apoferritin: A Novel "Theranostic" Agent To Prevent Hepatocellular Damage in Toxic Induced Acute Hepatitis. Mol. Pharm. 2013, 10, 2079-2085. [CrossRef] [PubMed]

74. Laura Conti, L.; Lanzardo, S.; Ruiu, R.; Cadenazzi, M.; Cavallo, F.; Aime, S.; Geninatti Crich, S. L-Ferritin targets breast cancer stem cells and delivers therapeutic and imaging agents. Oncotarget 2016, 7, 66713-66727.

75. Frank, N.Y.; Schatton, T.; Frank, M.H. The therapeutic promise of the cancer stem cell concept. J. Clin. Investig. 2010, 120, 41-50. [CrossRef] [PubMed]

76. Turino, L.N.; Ruggiero, M.R.; Stefanìa, R.; Cutrin, J.C.; Aime, S.; Geninatti Crich, S. Ferritin Decorated PLGA/Paclitaxel Loaded Nanoparticles Endowed with an Enhanced Toxicity Toward MCF-7 Breast Tumor Cells. Bioconj. Chem. 2017, 28, 1283-1290. [CrossRef] [PubMed]

77. Cutrin, J.C.; Alberti, D.; Bernacchioni, C.; Ciambellotti, S.; Turano, P.; Luchinat, C.; Geninatti-Crich, S.; Aime, S. Cancer cell death induced by ferritins and the peculiar role of their labile iron pool. Oncotarget 2018, 9, 27974-27984. [CrossRef] [PubMed]

78. Torti, S.V.; Torti, F.M. Iron and cancer: More ore to be mined. Nat. Rev. Cancer 2013, 342, 342-355. [CrossRef] [PubMed]

(C) 2019 by the authors. Licensee MDPI, Basel, Switzerland. This article is an open access article distributed under the terms and conditions of the Creative Commons Attribution (CC BY) license (http:/ / creativecommons.org/licenses/by/4.0/). 